\title{
Oil and Protein Stability in Some Camelina (Camelina sativa L. Crantz) Genotypes
}

\author{
İlhan Subaşı1 ${ }^{1, a, *}$, Yusuf Arslan ${ }^{2, b}$, Safure Güler ${ }^{3, c}$, Halil Hatipoğllu ${ }^{4, d}$, Servet Abrak ${ }^{4, e}$, Arzu Köse $^{5, f}$ \\ ${ }^{I}$ Department of Seed Science and Technology, Faculty of Agriculture, Bolu Abant İzzet Baysal University, 14030 Bolu, Turkey \\ ${ }^{2}$ Department of Field Crops, Faculty of Agriculture, Bolu Abant Izzet Baysal University, 14030 Bolu, Turkey \\ ${ }^{3}$ Department of Food Quality and Technology, Central Research Institute for Field Crops, 06170 Ankara, Turkey \\ ${ }^{4}$ Department of Field Crops GAP Agricultural Research Institute, 63040 Sanliurfa, Turkey \\ ${ }^{5}$ Department of Oilseed Crops, Transitional Zone Agricultural Research Institute, 26200 Eskişehir, Turkey \\ *Corresponding author
}

A R T I C L E IN F O A B S T R A C T

Research Article

Camelina sativa L. Crantz., which draws attention with its non-food use (biodiesel, animal feed etc.) against the increasing demand for oilseeds worldwide, is a good alternative plant. It is important to identify suitable and stable genotypes for regions along with high protein and oil content. The purpose of this study, camelina genotypes of Turkey in 3 different locations (Ankara, Ankara, Eskisehir) to investigate the quality characteristics in terms of genotype environment interactions in unirrigated and unfertilized conditions. 36 different genotypes, purified lines by negative selection, were analysed with 3 standard genotypes with augmented trial design. Environmental $(E)$, genotype $(G)$ and $G \times E$ interactions, which are sources of variation for protein and oil content, have been shown to be important. Oil and protein content were found ranged from $34.35 \%-37.88 \%$ and $25.76 \%-27.64 \%$ respectively. We have obtained important findings in our

Keywords: study to see the performance of Camelina sativa, and the possibility of alternative oil plants for these regions. In terms of correlation of protein ratio and oil ratio, genotypes with high value that Oil content Protein content Stability were least affected by each other were determined. The results showed that genotype selection by regions is important in terms of protein and oil ratio.

il81su@gmail.com (iD)https://orcid.org/0000-0001-7237-937X safureguler@hotmail.com iD https://orcid.org/0000-0003-3269-8303 servet.abrak@tarimorman.gov.tr (iD https://orcid.org/0000-0002-3872-1423

\section{d}

(1) yusuf.arslan@ibu.edu.tr halil.hatipoglu@tarimorman.gov.tr arzu.kose@tarimorman.gov.tr l id https://orcid.org/0000-0001-8496-6037 iDhttps://orcid.org/0000-0002-8456-2320 iDhttps://orcid.org/0000-0003-0675-8958

\section{Introduction}

The natural growing region of Camelina sativa, which is also known by names like false flax, German sesame, Siberian oilseed, is Mediterranean and Central Asia (Mcvay and Lamb, 2008; Putnam et al., 1993). The plant's cultivation started in the Neolithic age and was used as an oil plant throughout the Iron Age. It is reported that it was grown in a wide area up to Southeast Europe and Southwest Asian steppes during the Roman Empire (Putnam et al., 1993). Today, it is a little bit cultivated in Canada (Downey, 1971; Robinson, 1987), Germany, Poland and the former Soviet Union. The plant is an annual plant that can be grown both winter and summer. In recent years, it has increased its usage mainly as biofuel raw material (Vollmann et al., 2007). There are 7 commonly known species of the Camelina Crantz genus, including the camelina plant. These; $C$. sativa (L.) Crantz., C. laxa C. A. Mey, C. rumelica, C. microcarpa Andrz. ex DC., C. hispida Boiss., C. anomala Boiss. \& Hausskn. and $C$. alpkoyensis Y1ld. (Güner et al., 2012). The cultivated species is Camelina sativa (Kurt and Seyis, 2008).

Camelina oil contains many natural antioxidants such as tocopherols, which make the oil stable and used as cooking oil. The amount of tocopherols in oil is $700 \mathrm{mg} /$ $\mathrm{kg}$ (Kurt and Seyis, 2008). The most important feature of the camelina plant is the high rate of linolenic acid (38\%) contained in camelina oil. Linolenic acid is one of the OMEGA-3 fatty acids, which is a quality fatty acid found only in fish oil and flax. In a study done in Ireland, it was found that linoleum oil contains around $35-40 \%$ linolenic acid, while this ratio is around $8 \%$ in rapeseed and soy. Therefore, it is seen that ketchup is important in meeting OMEGA-3 fatty acid rich edible oil demand (Crowley and Fröhlich, 1998). In addition, in a clinical study conducted in comparison with camelina oil and olive-rapeseed oil, 
camelina oil contains 2.5 times more linolenic acid compared to rapeseed oil and 4 times more compared to olive oil, and accordingly, linoleum oil is $12 \%$. It is stated that while decreasing 2, rapeseed oil decreases by $5.4 \%$ and olive oil by $7.7 \%$ (Karvonen et al., 2002). It provides high levels of OMEGA-3 fatty acid in meat and eggs produced by using the linens plant in the nutrition of eggs and broilers, and helps to produce healthier meat and eggs for human health (Rokka et al., 2002; Ryhänen et al., 2007). Camelina flour is similar in biological value to soy flour and contains 45-47\% crude protein and 10-11\% fiber (Korsrud et al., 1978). The plant is also an important source of biodiesel, and the oils obtained from the plant are used in machine lubrication in the industry. The high iodine value of the methyl ester of camelina oil allows the oil to be used in machine lubrication for a longer time without deterioration (Fröhlich and Rice, 2005).

The remaining cake of oil after the oil extract of the camelina seed contains $10 \%$ oil, $45 \%$ protein, $13 \%$ fiber, $5 \%$ mineral substance, a small amount of vitamins and also contains certain secondary metabolites, glucosinolates, sinapines, tannins and phytate which are anti-nutrients if present at high levels. Camelina meal contains a low amount of glucosinolates (14.5-36.2 mmol kg-1) compared to other crucifers like rapeseed (100-120 mmol kg-1) and mustard (62.4-77.1 mmol kg-1) (Berhow et al., 2013). It is a cheap source of protein and lipid (rich in n-3 an n-6 fatty acids) for live-stock feed (Pilgeram et al., 2007). But, glucosinolates in meal are reduced either by heating it at $100^{\circ} \mathrm{C}$ for $30 \mathrm{~min}$ or by soaking it in water (Tyagi, 2002). On the other hand, since the amino acid distribution of the camelina meal is largely similar to that of the soybean meal, it has the feature of being an alternative to soy. The composition of amino acids in camelina protein is particularly suitable for feeding poultry. It is also stated that camelina meal is a high source of protein and energy for ruminant animals (Bertrand and Brühl, 2001; Schuster and Friedt, 1998).

Camelina ability to adapt to extreme conditions is high, and the plant is not too demanding in terms of nutrients. The high competition of the plant against weeds limits the use of chemical drugs. This situation is an important feature for the environment (Kurt and Seyis, 2008).

Although the camelina plant has many uses, there has not been enough scientific research on the plant in our country and in the world. After the importance of oil in terms of human health has emerged in recent years, it has attracted attention and characterization and adaptation studies have started in many countries, especially in Germany. It has attracted attention again in recent years due to its low environmental demand and high quality of fatty acids. The fact that it can be grown in marginal areas especially highlights the plant as an important alternative oil plant. Therefore, good genotypes should be obtained by breeding studies. İdeal genotypes are highly efficient as well as stable. For this reason, determine of stable varieties with multienvironmental trials are important in plant breeding for evaluating genotypes for stability and adaptability of genotype by environment (GE) interaction. (Montesinoslópez et al., 2018).

Yan and Rajcan (2002) demonstrated that can be used a genotype $\mathrm{x}$ property (GP) biplot (with an application of the GGE biplot technique) to study genotype $\mathrm{x}$ property data. This application of GP biplot was an excellent for visualizing genotype $\mathrm{x}$ property data. Within the scope of this study, 36 different camelina lines were examined in terms of protein and oil content in 3 locations of Turkey and data presented to the use of breeders and scientists.

\section{Material and Method}

\section{Material}

The seeds of 36 camelina genotypes (Camelina sativa (L.) Crantz) used in the study, obtained from The Seed Bank of The Agricultural Research Service of The United States Department of Agriculture (USDA) (Table 1). Additionaly 3 control (C) genotyps (Line-1 (C1), PI 650149 (C2) and PI 650151 (C3)) were used in the trial. Field experiments were conducted during the 2014-2015 cropping season at the research and implementation area of Field Crops Agricultural Research Institute, Ankara, GAP Agricultural Research Institute, Şanlıurfa and Transitional Zone Agrıcultural Research Instıtute, Eskişehir in Turkey. Climatic data of these locations are shown in Figure 1.

\section{Method}

Field experiments were conducted during the 20142015 cropping season. The materials were examined in the Augmented trial pattern in three locations on October, 15 $\mathrm{cm}$ between rows, $5 \mathrm{~cm}$ above the row and 5 meters in row length, and were examined in terms of their oil and protein content. No irrigation and fertilization process were applied during the vegetation period.

The oil content $(\%)$ was determined from the seeds of 10 plants selected randomly from the plant rows. Oil ratio analyzes were performed with the Soxhlet extractor (Soxtherm 2000 automatic, C. Gerhardt GmbH \& Co. KG, Königswinter, Germany) using the method reported by Bertrand and Brühl (2001). The homogenous sample, taken from each row of camelina seeds, was ground. Crude oil weight obtained from the $5 \mathrm{~g}$ sample taken was determined in proportion to the sample weight.

The protein ratio of homogenous sample taken from camelina seeds obtained from each row was made by Dumas method (Velp Scientifica NDA-701) according to AOAC 992.23: Crude Protein in Cereal Grains and Oilseeds method. In the calculation of the protein, the nitrogen factor was taken as 6.25.

Data were analysed using the statistical analysis software JMP Pro 13 (SAS Institute, NC, USA, 2013), while the bi-plot graph was produced with GEA-R statistical software for visual evaluation of protein and oil performance and stability of genotyps across environments. Properties values means were compared using the Duncan test with XLSTAT statistical software.

\section{Findings and Discussion}

Field trials were established in Ankara, Şanlıurfa and Eskişehir locations in October 2014. Harvesting was in the middle of June in Eskişehir and Ankara, in the middle of May in Şanliurfa in 2015. Oil content and protein content are determined. 
40

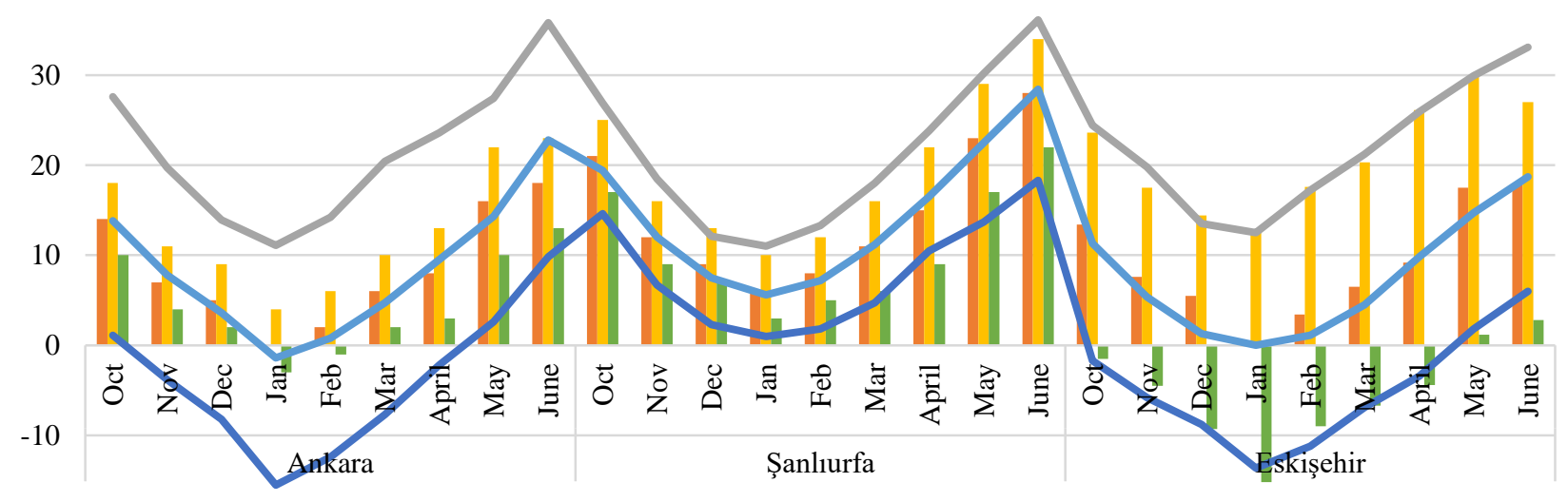

$-20$

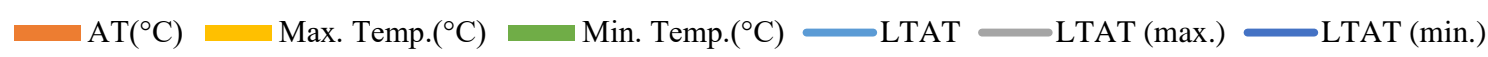

(a)

160

140

120

100

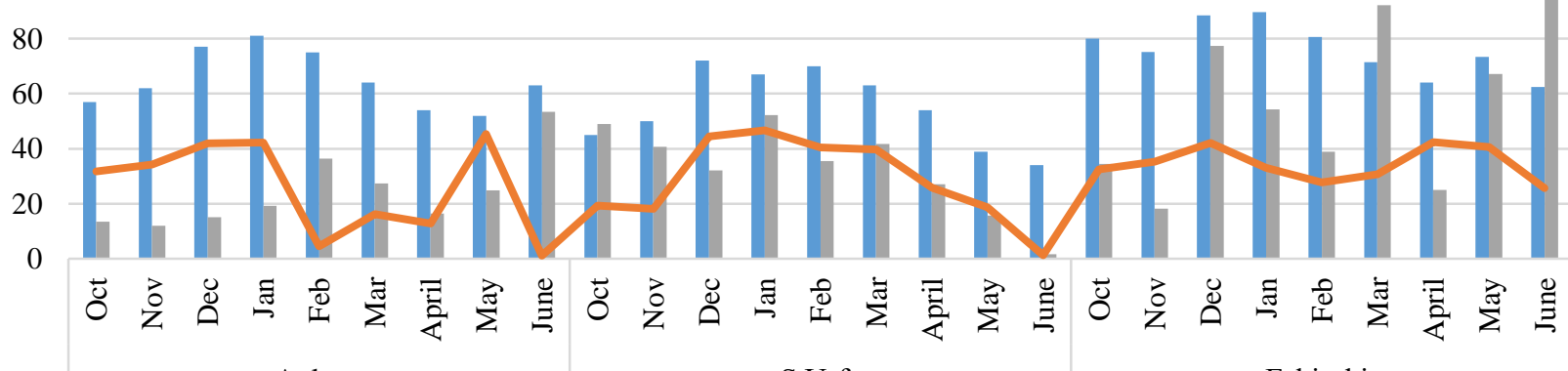

Ankara

Ş.Urfa

Eskişehir

Humidity $(\%) —$ Preciptation $(\mathrm{mm}) \quad$ LTAP $(\mathrm{mm})$

(b)

Figure 1. Monthly average of meteorological data of the experimental farm during growing season (2014-2015) and long-term values ((a): average temperature (AT), maximum temperature (Max. Temp.), minimum temperature (Min.

Temp.), long term average temperatures (LTAT max. and LTAT min.); (b): humidity, precipitation and long-term average preciptation (LTAP)

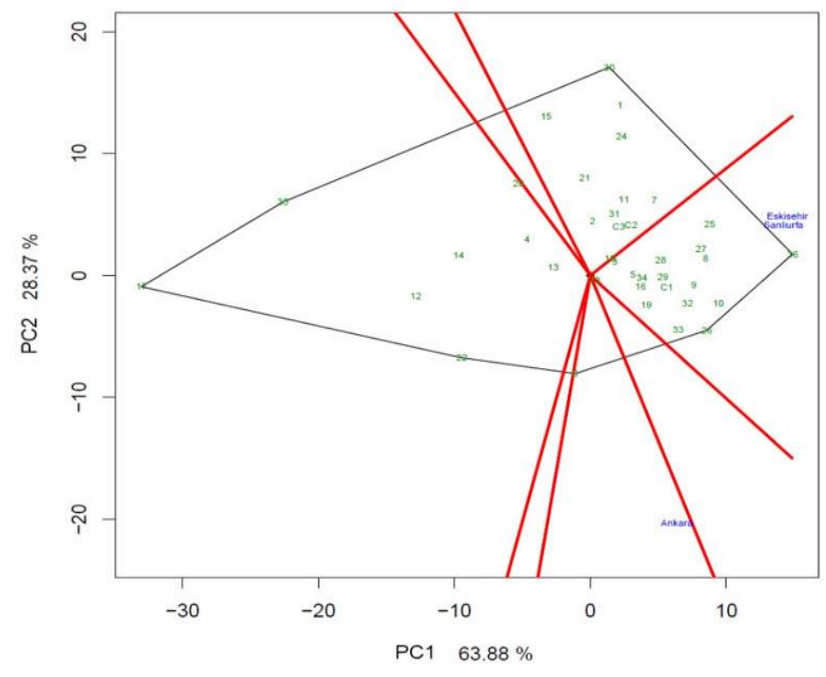

Figure 2. Polygon view of GGE-biplot plot for camelina genotypes and environments in oil ratio.

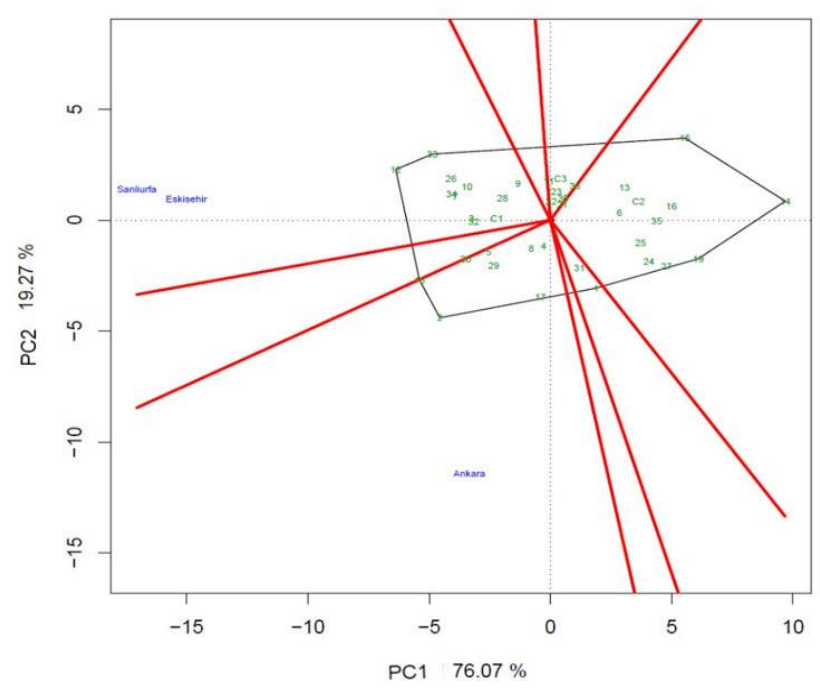

Figure 3. The polygon of the GGE-biplot plot for camelina genotypes and environments in protein ratio. 


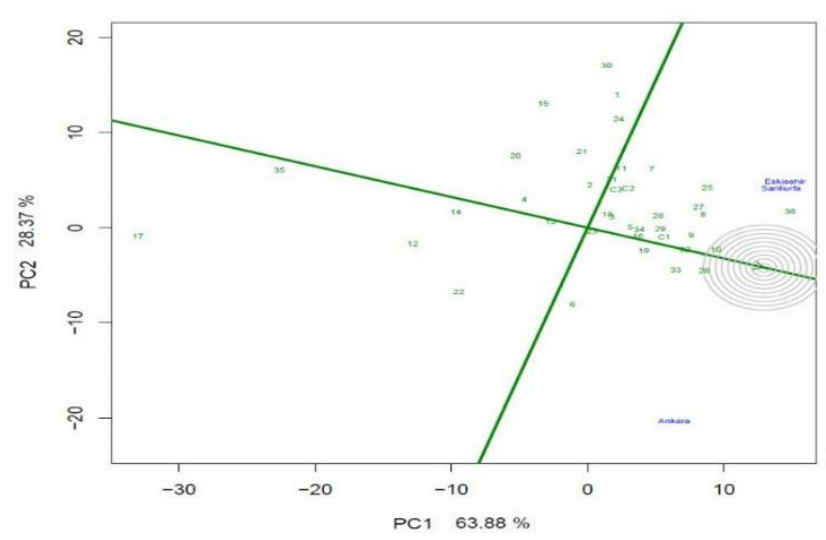

Figure 4. GGE-biplot chart based on comparison of genotypes with ideal genotype in oil ratio.

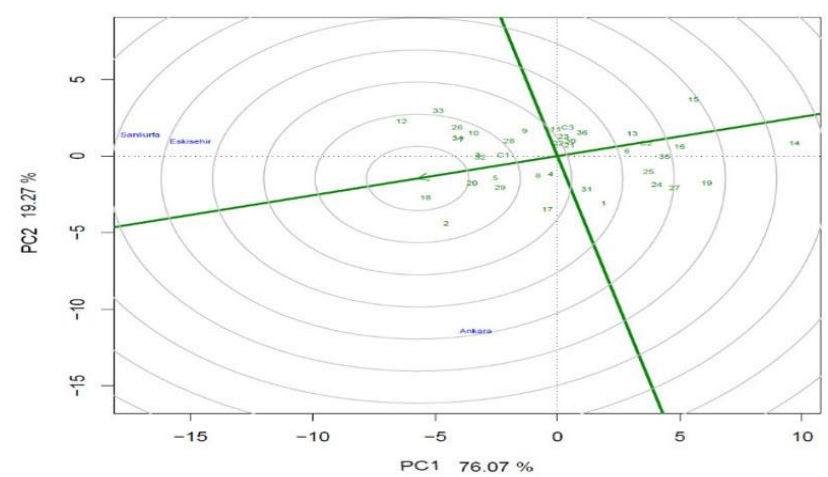

Figure 5. GGE-biplot graph based on comparison of genotypes with ideal genotype in protein ratio

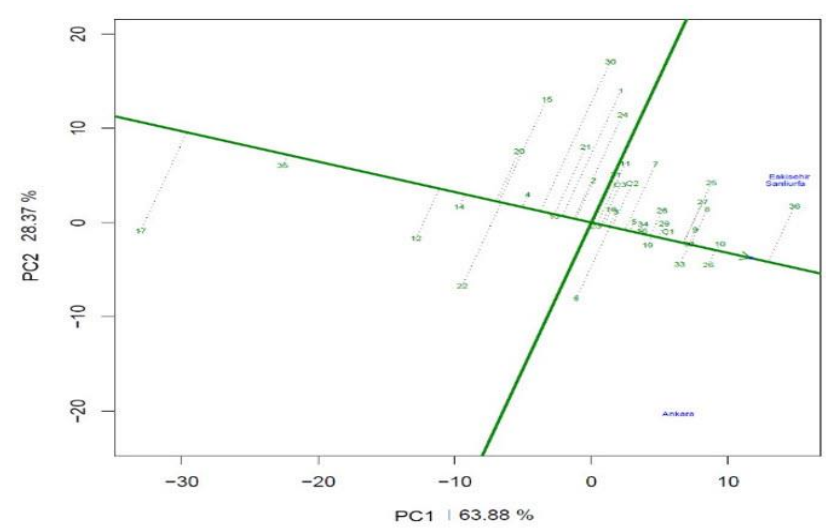

Figure 6. Average environmental coordination view of the DDE-biplot chart in the oil ratio.

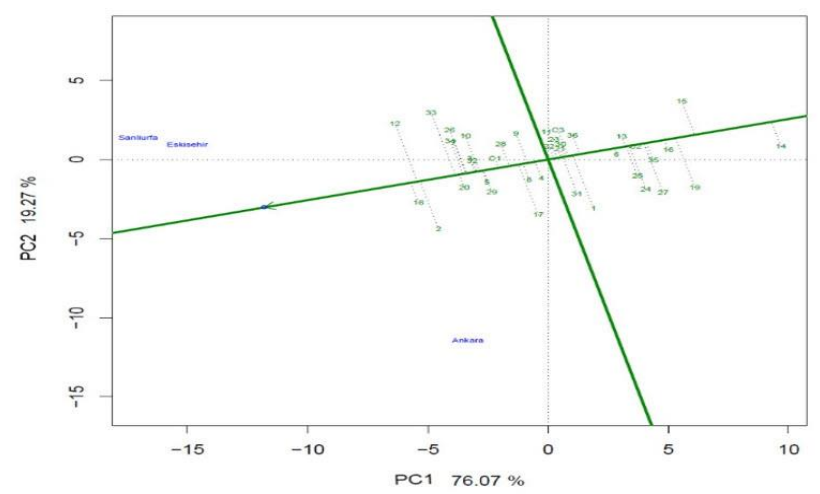

Figure 7. Average environmental coordination view of GGE-biplot graph in protein ratio
Analysis of variance revealed significant $(\mathrm{P}<0.01)$ effects for all sources of variation (environment, genotype and $\mathrm{G} \times \mathrm{E}$ interaction) for protein ratio and oil ratio (Table $2)$. The interaction between genotype and environment $(\mathrm{G} \times$ E interaction showing that genotypes do not give the same response in different environments) is important in terms of guiding breeders in the selection of regional genotypes (Ilker et al., 2018; Silveira et al., 2016). There was a statistically significant differences of oil and protein content values in Ankara, Şanlıurfa and Eskişehir location.

The highest oil rates were determined in Ankara, Şanlıurfa and Eskişehir locations with the rates of $43.53 \%$, $46.07 \%, 46.94 \%$, respectively, in genotype 6, 36 and 36 . The highest protein ratios were determined in Ankara, Şanlıurfa and Eskişehir locations with the rates of $31.05 \%, 34.01 \%$, $32.22 \%$ in genotype 2, 34 and 12, respectively. In terms of both of the characters examined, the accessions were in different groups at different locations. This emerged as a result of the genotype environment relationship

Polygon charts showing genotype $(\mathrm{G})$ and genotype $\mathrm{x}$ environment interaction (GE) in experiments in multiple environments are shown in Figure 2 and Figure 3. In terms of oil ratio, it is seen that genotype 36 was more prominent in Eskişehir and Şanlıurfa, these two locations affect the genotypes similarly, and genotype 6 was prominent in the Ankara location (Figure 2). In terms of protein ratio, it was determined that genotype 12 and genotype 33 in Eskişehir and Şanlıurfa regions and genotype 2 in Ankara location were found to be prominent (Figure 3).

The GGE biplot in Figure 4 and Figure 5 show that genotyps possitions according to ideal enviroments. The central circle is calculated and as ideal environment is considered. It is seen that the closest environments to the ideal environment, in terms of oil ratio (Figure 4) and protein ratio (Figure 5) are Eskişehir and Şanlıurfa locations. Likewise, it was observed that the ideal genotypes, in terms of oil ratio were genotype 26 and genotype 10 (Figure 4), and the ideal genotypes, in terms of protein ratio were 20 and 18 genotypes (Figure 5).

The ideal test environment should have the larger PC1 (expressing the main genotypic effect) score and the smaller absolute PC2 (more representative of the whole environment) score. Although it is not really an ideal environment, the ideal test environment can be used as a reference in multiple environment trials (Kaya et al., 2006). When the yield performance and stability of genotypes are evaluated with the average environmental coordination method, an average environment is defined by this method (Yan and Hunt, 2001). Scores of PC1 and PC2 average of all circles intersect is indicated by a small circle. By drawing a line through this mean circumference point and the biplot origin, the average circumference abscissa of the mean perimeter coordination is formed. Absis means that while the average circumferential direction is unidirectional, genotypes' oil ratios (Figure 6) and protein ratios (Figure 7) increase in this direction. The other line drawn as ordinate expresses that the stability decreases in both directions from the origin point and the effect of genotype $\mathrm{x}$ environment interaction increases. Considering this situation, it was seen that the oil ratio, high value and stability were reached in the genotype 26 and genotype 10 , while the protein ratio was reached only in genotype 10 (Figure 6 and Figure 7). 


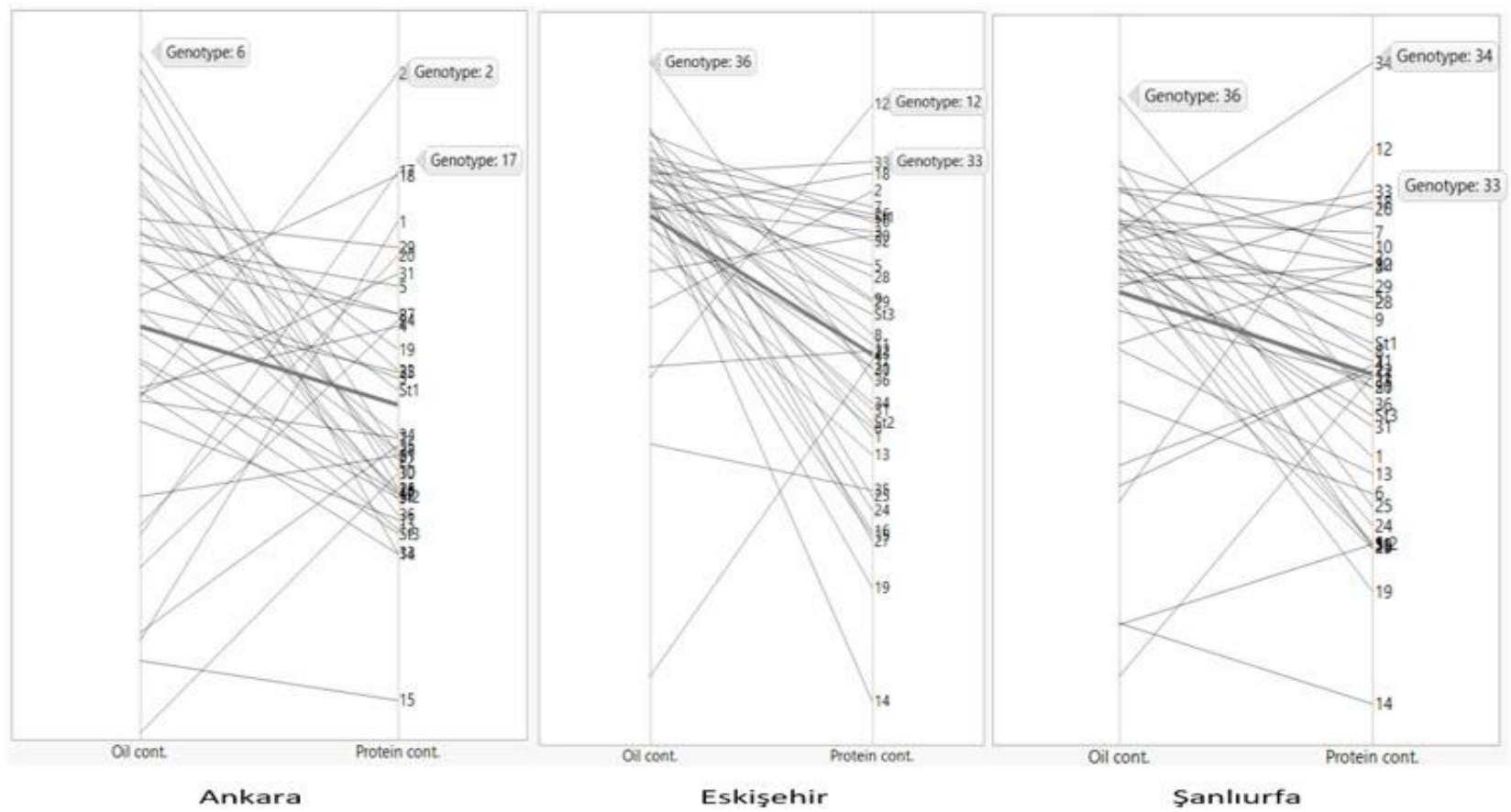

Figure 8. Parallel coordinate plot for oil and protein content.

Table 1. Materials used in the research and the countries they belong to.

\begin{tabular}{l|ccccc}
\hline \multicolumn{1}{c}{ Accessions ID } & Genotype No. & Origin & Accessions ID & Genotype No. & Origin \\
\hline PI 650141 & 1 & America, Minesota & PI 650155 & 19 & Poland \\
PI 650164 & 2 & Austria & PI 650158 & 20 & Poland \\
PI 597833 & 3 & Denmark & PI 650159 & 21 & Poland \\
PI 650142 & 4 & Denmark & PI 650162 & 22 & Poland \\
PI 650144 & 5 & Denmark & PI 650153 & 23 & Russia \\
PI 650150 & 6 & Denmark & PI 650154 & 24 & Russia \\
Ames 31220 & 7 & Georgia & PI 650156 & 25 & Russia \\
Ames 31224 & 8 & Georgia & PI 650157 & 26 & Russia \\
Ames 31231 & 9 & Georgia & PI 650160 & 27 & Russia \\
Ames 31232 & 10 & Georgia & PI 650161 & 28 & Russia \\
Einfact (Leindotter) & 11 & Germany & PI 650166 & 29 & Russia \\
PI 633193 & 12 & Germany & PI 652885 & 30 & Slovenia \\
PI 633194 & 13 & Germany & PI 652886 & 31 & Slovenia \\
PI 650145 & 14 & Germany & PI 304269 & 32 & Sweden \\
PI 650148 & 15 & Germany & PI 304270 & 33 & Sweden \\
PI 650149 & 16 & Germany & PI 304271 & 34 & Sweden \\
PI 311735 & 17 & Poland & PI 650147 & 35 & Sweden \\
PI 311736 & 18 & Poland & PI 650151 & 36 & Swiss \\
\hline
\end{tabular}

In our study, although the correlation between protein ratio and oil ratio is not statistically significant, the correlation between protein ratio and oil ratio of genotypes in 3 locations is seen in the parallel coordinate plot graph in Figure 8. In oil plants, the ratio of protein in the seed is as important as the oil ratio. Genotype 17 in Ankara location and Genotype 33 in Eskişehir and Şanlıurfa locations were the least negative effects of protein and oil ratios on each other.

Canvin (1965) observed seed development at different temperatures in oilseed plants such as rape, safflower, sunflower, flax and castor bean plants; found that the oil content of sunflower, safflower and castor bean was not affected by the temperature, and that the oil content of rapeseed and flax seeds was higher at low temperatures. Ayerza (2009) reported that when Chia genotypes were tested in 5 different ecosystems, protein and oil ratios differ in some locations. Popovic et al. (2016) stated that in their study on soybean genotypes in 2008, 2009 and 2010, protein and oil ratios changed over the years. They found that the amount of both protein and oil was higher in 2008 and 2009 compared to 2010. Similarly, the absence of a correlation between of protein and oil content in our study and the increase of both in some environments show that environmental factors are more determinant than genotypic factors in terms of these properties. 
Table 2. Results of analysis of variance for protein and oil content field trial data conducted with 36 camelina genotypes

\begin{tabular}{l|ccc}
\multicolumn{2}{c}{ in 3 environments. } & \multicolumn{2}{c}{ MS Protein Content Oil Content } \\
\hline \multicolumn{1}{c}{ Source } & DF & 7.210 & 38.778 \\
Model & 131 & $30.859^{* *}$ & $125.403^{* *}$ \\
Enviroment (E) & 2 & $1.093^{*}$ & $4.093^{* *}$ \\
Blocks [E] & 15 & $12.682^{* *}$ & $69.785^{* *}$ \\
Genotype (G) & 38 & $3.129^{* *}$ & $21.441^{* *}$ \\
E $\times$ G & 76 & 0.453 & 0.327 \\
Error & 30 & 2.503 & 1.565 \\
C.V. $(\%)$ & & &
\end{tabular}

DF: Degree of freedom, MS: Mean squares

Table 3. Corrected values obtained from Ankara, Şanlıurfa and Eskişehir locations and their groups.

\begin{tabular}{|c|c|c|c|c|c|c|}
\hline \multirow[b]{2}{*}{ Genotyps Numbers } & \multicolumn{2}{|c|}{ Ankara } & \multicolumn{2}{|c|}{ Şanliurfa } & \multicolumn{2}{|c|}{ Eskişehir } \\
\hline & $\begin{array}{c}\text { Oil content } \\
(\%)\end{array}$ & $\begin{array}{c}\text { Protein content } \\
(\%)\end{array}$ & $\begin{array}{c}\text { Oil content } \\
(\%)\end{array}$ & $\begin{array}{c}\text { Protein content } \\
(\%)\end{array}$ & $\begin{array}{c}\text { Oil content } \\
(\%)\end{array}$ & $\begin{array}{c}\text { Protein content } \\
(\%)\end{array}$ \\
\hline 1 & $23.400^{\mathrm{kl}}$ & $28.810^{\text {ac }}$ & $40.090^{\mathrm{c}-\mathrm{h}}$ & $25.920^{1-q}$ & $40.960^{c-g}$ & $25.880^{\mathrm{i}-\mathrm{p}}$ \\
\hline 2 & $31.720^{\mathrm{f}-\mathrm{j}}$ & $31.050^{\mathrm{a}}$ & $42.750^{\mathrm{bc}}$ & $30.020^{b-g}$ & $31.780^{t}$ & $30.570^{\mathrm{acc}}$ \\
\hline 3 & $35.600^{c-g}$ & $26.450^{-\mathrm{cj}}$ & $37.120^{\mathrm{i}-1}$ & $29.840^{\mathrm{b}-\mathrm{h}}$ & $37.990^{1-\mathrm{p}}$ & $29.800^{\mathrm{a}-\mathrm{f}}$ \\
\hline 4 & $32.060^{-\mathrm{fj}}$ & $27.230^{\mathrm{b}-\mathrm{h}}$ & $27.400^{\circ}$ & $27.800^{\mathrm{f}-\mathrm{m}}$ & $39.620^{\mathrm{g}-\mathrm{m}}$ & $27.400^{\mathrm{d}-\mathrm{m}}$ \\
\hline 5 & $37.000^{b-g}$ & $27.840^{\mathrm{b}-\mathrm{e}}$ & $37.790^{\mathrm{h}-1}$ & $29.190^{\mathrm{c}-\mathrm{j}}$ & $38.660^{\mathrm{j}-\mathrm{o}}$ & $29.150^{\mathrm{b}-\mathrm{g}}$ \\
\hline 6 & $43.530^{\mathrm{a}}$ & $25.290^{\mathrm{e}-\mathrm{k}}$ & $31.470^{\mathrm{n}}$ & $25.160^{\mathrm{n}-\mathrm{r}}$ & $35.790^{\mathrm{qr}}$ & $26.050^{\mathrm{h}-\mathrm{o}}$ \\
\hline 7 & $31.610^{\mathrm{f}-\mathrm{j}}$ & $25.550^{\mathrm{d}-\mathrm{k}}$ & $40.140^{\mathrm{c}-\mathrm{h}}$ & $30.510^{\mathrm{b}-\mathrm{e}}$ & $41.040^{\mathrm{c}-\mathrm{g}}$ & $30.270^{a-d}$ \\
\hline 8 & $37.310^{a-g}$ & $27.420^{b-f}$ & $41.680^{\mathrm{b}-\mathrm{e}}$ & $28.070^{\mathrm{e}-\mathrm{m}}$ & $42.580^{\mathrm{bc}}$ & $27.830^{c-k}$ \\
\hline 9 & $39.110^{\mathrm{a}-\mathrm{e}}$ & $24.630^{\mathrm{h}-\mathrm{k}}$ & $40.630^{\mathrm{b}-\mathrm{g}}$ & $28.750^{\mathrm{d}-\mathrm{k}}$ & $41.530^{\mathrm{b}-\mathrm{f}}$ & $28.510^{\mathrm{b}-\mathrm{i}}$ \\
\hline 10 & $41.110^{\mathrm{a}-\mathrm{c}}$ & $25.050^{\mathrm{f}-\mathrm{k}}$ & $41.520^{\mathrm{b}-\mathrm{e}}$ & $30.220^{b-f}$ & $42.420^{\text {bcd }}$ & $29.980^{a-e}$ \\
\hline 11 & $30.910^{\mathrm{g}-\mathrm{j}}$ & $24.320^{i-k}$ & $38.640^{\mathrm{f-k}}$ & $27.880^{\mathrm{f}-\mathrm{m}}$ & $39.540^{\mathrm{g}-\mathrm{n}}$ & $27.640^{\mathrm{c}-1}$ \\
\hline 12 & $33.900^{\mathrm{d}-\mathrm{h}}$ & $24.710^{\mathrm{g}-\mathrm{k}}$ & $26.650^{\circ}$ & $32.260^{\mathrm{ab}}$ & $27.520^{\mathrm{u}}$ & $32.220^{\mathrm{a}}$ \\
\hline 13 & $34.700^{c-h}$ & $24.170^{\mathrm{jk}}$ & $33.960^{\mathrm{m}}$ & $25.570^{\mathrm{m}-\mathrm{r}}$ & $34.83^{\mathrm{rs}}$ & $25.530^{\mathrm{j}-\mathrm{p}}$ \\
\hline 14 & $31.910^{\mathrm{f}-\mathrm{j}}$ & $23.800^{\mathrm{kl}}$ & $20.830^{p}$ & $20.840^{\mathrm{s}}$ & $38.730^{\mathrm{i}-\mathrm{o}}$ & $20.830^{\mathrm{q}}$ \\
\hline 15 & $22.700^{\mathrm{kl}}$ & $21.590^{1}$ & $36.220^{\mathrm{k}-\mathrm{m}}$ & $24.040^{\mathrm{qr}}$ & $37.090^{o-q}$ & $24.000^{n-p}$ \\
\hline 16 & $38.100^{\mathrm{a}-\mathrm{f}}$ & $24.720^{\mathrm{g}-\mathrm{k}}$ & $37.960^{\mathrm{g}-1}$ & $24.120^{\mathrm{qr}}$ & $38.830^{\mathrm{h}-\mathrm{o}}$ & $24.080^{\mathrm{n}-\mathrm{p}}$ \\
\hline 17 & $27.010^{i-k}$ & $29.560^{\mathrm{ab}}$ & $18.260^{9}$ & $27.580^{\mathrm{g}-\mathrm{n}}$ & $9.160^{\mathrm{w}}$ & $27.340^{\mathrm{d}-\mathrm{m}}$ \\
\hline 18 & $35.210^{c-g}$ & $29.510^{\mathrm{ab}}$ & $36.930^{j-1}$ & $31.150^{\mathrm{b}-\mathrm{d}}$ & $37.830^{\mathrm{m}-\mathrm{p}}$ & $30.910^{\mathrm{ab}}$ \\
\hline 19 & $39.630^{a-d}$ & $26.890^{\mathrm{c}-\mathrm{i}}$ & $38.460^{\mathrm{f}-1}$ & $23.150^{\mathrm{r}}$ & $38.280^{\mathrm{k}-\mathrm{p}}$ & $23.000^{\mathrm{pq}}$ \\
\hline 20 & $27.330^{\mathrm{i}-\mathrm{k}}$ & $28.290^{\mathrm{bc}}$ & $34.230^{\mathrm{m}}$ & $29.870^{\mathrm{b}-\mathrm{h}}$ & $34.050^{\mathrm{s}}$ & $29.720^{\mathrm{a}-\mathrm{f}}$ \\
\hline 21 & $28.330^{\mathrm{h}-\mathrm{k}}$ & $25.280^{e-k}$ & $37.620^{\mathrm{h}-1}$ & $27.340^{\mathrm{h}-\mathrm{o}}$ & $37.440^{\mathrm{o}-\mathrm{q}}$ & $27.190^{\mathrm{e}-\mathrm{m}}$ \\
\hline 22 & $39.730^{a-d}$ & $25.220^{\mathrm{e}-\mathrm{k}}$ & $28.390^{\circ}$ & $27.670^{\mathrm{f}-\mathrm{n}}$ & $28.210^{\mathrm{u}}$ & $27.520^{\mathrm{d}-1}$ \\
\hline 23 & $36.600^{\mathrm{b}-\mathrm{g}}$ & $24.760^{\mathrm{g}-\mathrm{k}}$ & $35.810^{\mathrm{lm}}$ & $27.510^{\mathrm{g}-\mathrm{n}}$ & $36.680^{\mathrm{pq}}$ & $27.470^{\mathrm{d}-1}$ \\
\hline 24 & $25.900^{\mathrm{j}-1}$ & $27.320^{b-g}$ & $39.630^{\mathrm{d}-\mathrm{j}}$ & $24.510^{\mathrm{p}-\mathrm{r}}$ & $40.500^{e-j}$ & $24.470^{\mathrm{m}-\mathrm{p}}$ \\
\hline 25 & $34.730^{\mathrm{c}-\mathrm{h}}$ & $26.540^{-\mathrm{cj}}$ & $43.020^{\mathrm{b}}$ & $24.890^{0-r}$ & $42.840^{\mathrm{b}}$ & $24.740^{1-\mathrm{p}}$ \\
\hline 26 & $42.940^{\mathrm{ab}}$ & $24.790^{\mathrm{f}-\mathrm{k}}$ & $41.670^{\mathrm{b}-\mathrm{e}}$ & $31.020^{\mathrm{b}-\mathrm{d}}$ & $40.240^{\mathrm{e}-\mathrm{j}}$ & $30.130^{a-e}$ \\
\hline 27 & $36.430^{\mathrm{b}-\mathrm{g}}$ & $27.420^{\mathrm{b}-\mathrm{f}}$ & $42.160^{b-d}$ & $24.040^{\mathrm{qr}}$ & $41.980^{\mathrm{b}-\mathrm{e}}$ & $23.890^{\circ \mathrm{p}}$ \\
\hline 28 & $36.430^{b-g}$ & $25.370^{\mathrm{e}-\mathrm{k}}$ & $39.970^{\mathrm{d}-\mathrm{h}}$ & $29.090^{c-k}$ & $39.790^{\mathrm{f}-1}$ & $28.940^{\mathrm{b}-\mathrm{h}}$ \\
\hline 29 & $37.840^{a-f}$ & $28.420^{\mathrm{bc}}$ & $38.700^{\mathrm{f-k}}$ & $29.410^{c-i}$ & $40.650^{\mathrm{d}-\mathrm{h}}$ & $28.460^{\mathrm{b}-\mathrm{j}}$ \\
\hline 30 & $20.230^{1}$ & $25.010^{\mathrm{f}-\mathrm{k}}$ & $40.750^{b-f}$ & $27.340^{\text {h-o }}$ & $40.570^{\mathrm{e}-\mathrm{i}}$ & $27.190^{\mathrm{e}-\mathrm{m}}$ \\
\hline 31 & $31.830^{\mathrm{f}-\mathrm{j}}$ & $28.020^{b-d}$ & $38.460^{\mathrm{f}-1}$ & $26.540^{k-q}$ & $38.280^{\mathrm{k}-\mathrm{p}}$ & $26.390^{\mathrm{g}-\mathrm{o}}$ \\
\hline 32 & $40.410^{\mathrm{a}-\mathrm{d}}$ & $26.570^{\mathrm{c}-\mathrm{j}}$ & $40.000^{\mathrm{d}-\mathrm{h}}$ & $29.860^{b-h}$ & $40.900^{\mathrm{c}-\mathrm{g}}$ & $29.620^{\mathrm{a}-\mathrm{f}}$ \\
\hline 33 & $42.310^{\mathrm{ab}}$ & $23.810^{\mathrm{kl}}$ & $39.080^{e-j}$ & $31.370^{\mathrm{bc}}$ & $39.980^{\mathrm{f}-\mathrm{k}}$ & $31.130^{\mathrm{ab}}$ \\
\hline 34 & $37.410^{\mathrm{a}-\mathrm{g}}$ & $25.580^{\mathrm{d}-\mathrm{k}}$ & $39.580^{\mathrm{d}-\mathrm{j}}$ & $34.010^{\mathrm{a}}$ & $37.710^{\mathrm{n}-\mathrm{p}}$ & $26.520^{\mathrm{g}-\mathrm{o}}$ \\
\hline 35 & $23.660^{\mathrm{kl}}$ & $25.430^{\mathrm{d}-\mathrm{k}}$ & $20.750^{p}$ & $24.120^{\mathrm{qr}}$ & $23.460^{\mathrm{v}}$ & $24.860^{k-p}$ \\
\hline 36 & $38.900^{a-e}$ & $24.390^{\mathrm{ijk}}$ & $46.070^{\mathrm{a}}$ & $27.000^{i-p}$ & $46.940^{\mathrm{a}}$ & $26.960^{\mathrm{f}-\mathrm{n}}$ \\
\hline $\mathrm{C} 1$ & $38.683^{\mathrm{a}-\mathrm{e}}$ & $26.270^{\mathrm{c}-\mathrm{k}}$ & $39.817^{\mathrm{d}-\mathrm{i}}$ & $28.250^{e-1}$ & $39.600^{\mathrm{g}-\mathrm{m}}$ & $30.058^{a-e}$ \\
\hline $\mathrm{C} 2$ & $33.017^{-\mathrm{i}}$ & $24.645^{\mathrm{h}-\mathrm{k}}$ & $39.157^{\mathrm{e}-\mathrm{j}}$ & $24.148^{\mathrm{qr}}$ & $38.875^{\text {h-o }}$ & $26.143^{\mathrm{h}-\mathrm{o}}$ \\
\hline C3 & $32.900^{e-i}$ & $24.108^{\mathrm{jk}}$ & $38.383^{\mathrm{f}-1}$ & $26.760^{-\mathrm{p}}$ & $38.367^{\mathrm{k}-\mathrm{p}}$ & $28.217^{\mathrm{b}-\mathrm{j}}$ \\
\hline Std. Dev. & 5.299 & 1.819 & 5.538 & 2.662 & 5.465 & 2.378 \\
\hline Minimum & 20.230 & 21.590 & 18.260 & 20.840 & 9.160 & 20.830 \\
\hline Maximum & 43.530 & 31.050 & 46.070 & 34.010 & 46.940 & 32.220 \\
\hline Means & 34.354 & 25.758 & 37.380 & 27.271 & 37.879 & 27.643 \\
\hline
\end{tabular}


Likewise, Gurmu et al., (2010) in their study with soy genotypes in 6 environments in 2007, stated that 2 genotypes out of 3 genotypes were not stable in terms of protein, that is, they were greatly affected by environmental conditions. Our findings in Camelina genotypes show that environmental conditions can increase the amount of protein and oil together.

\section{Conclusion}

In this study, it was observed that the environmental conditions in which the camelina plant grows affected the oil and protein ratio in a statistically significant way. Since oil plants are also a source of feed stuff, the high ratio of protein as well as the high oil ratio in the seed is important, so the selection of genotypes with good oil and protein ratio should be considered. This study showed that the negative relationship between the oil and the protein ratio in camelina seeds appeared in all environments. In addition, in this study, Camelina sativa genotypes with the least negative correlation of oil and protein ratio were determined (Genotype 17 and Genotype 33). Genotypes took place in different sequences in different environmental conditions in terms of oil and protein ratio. This situation shows that it is insufficient to carry out improvement studies in a single location. Selection studies in countries such as Turkey which is very different climate zones should be carried out in very different climatic zones as possible and environment-specific varieties must be developed. Instead of stable varieties, environmentally specific varieties should be recommended.

\section{References}

Ayerza R. 2009. The Seed's protein and oil content, fatty acid composition, and growing cycle length of a single genotype of chia (Salvia hispanica L.) as affected by environmental factors. J. Oleo Sci. 58: 347-554. https://doi.org/10.5650/ jos.58.347

Berhow MA, Polat U, Glinski JA, Glensk M, Vaughn SF, Isbell T, Ayala-Diaz I, Marek L, Gardner C. 2013. Optimized analysis and quantification of glucosinolates from Camelina sativa seeds by reverse-phase liquid chromatography. Ind. Crops Prod. 43: 119-125. https://doi.org/10.1016/j.indcrop. 2012.07.018

Bertrand M, Brühl L. 2001. Comparison of Different Methods for the Determination of the Oil Content in Oilseeds. J. Am. Oil Chem. Soc. 78: 95-102. https://doi.org/10.1007/s11746-0010226-y

Canvin DT. 1965. The Effect of Temperature on the Oil Content and Fatty Acid Composition of the Oils From Several Oil Seed Crops. Can. J. Bot. 43: 63-69. https://doi.org/10.1139/b65-008

Crowley JG, Fröhlich A. 1998. Factors Affecting the Composition and Use of Camelina 1-23.

Downey RK. 1971. Agricultural and genetic potentials of cruciferous oilseed crops. J. Am. Oil Chem. Soc. 48: 718-722. https://doi.org/10.1007/BF02638528

Fröhlich A, Rice B. 2005. Evaluation of Camelina sativa oil as a feedstock for biodiesel production. Ind. Crops Prod. 21: 25-31. https://doi.org/10.1016/j.indcrop.2003.12.004

Güner A, Aslan S, Ekim, T, Vural M, Babaç MT. 2012. Türkiye bitkileri listesi (damarlı bitkiler), Nezahat Gökyiğit Botanik Bahçesi ve Flora Araştırmaları Derneği Yayını. İstanbul.

Gurmu F, Mohammed H, Alemaw G. 2010. Genotype X environment interactions and stability of soybean for grain yield and nutrition quality. African Crop Sci. J. 17. https://doi.org/10.4314/acsj.v17i2.54202
Ilker E, Kocaturk M, Kadiroglu A, Altinbas M, Yildirim A, Ozturk G, Yildiz H. 2018. Stability Analyses For Double Cropping In Soybean [(Glycine max L.) Merrill]. Turkish J. F. Crop. 80-84. https://doi.org/10.17557/tjfc.467434

Karvonen HM, Aro A, Tapola NS, Salminen I, Uusitupa MIJ, Sarkkinen ES. 2002. Effect of $\alpha$-linolenic acid-rich Camelina sativa oil on serum fatty acid composition and serum lipids in hypercholesterolemic subjects. Metabolism. 51: 1253-1260. https://doi.org/10.1053/meta.2002.35183

Kaya Y, Akçura M, Taner S. 2006. GGE-Biplot Analysis of MultiEnvironment Yield Trials in Bread Wheat 30: 325-337.

Korsrud GO, Keith MO, Bell JM. 1978. a Comparison of the Nutritional Value of Crambe and Camelina Seed Meals With Egg and Casein. Can. J. Anim. Sci. 58: 493-499. https://doi.org/10.4141/cjas78-063

Kurt O, Seyis F. 2008. Alternatif yağ bitkisi: Ketencik [Camelina sativa (L.) Crantz]. J. Fac. Agric. 23: 116-120.

Mcvay KA, Lamb PF. 2008. Camelina Production in Montana (Report) [WWW Document]. Bull. MT200701AG. URL http://www.msuextension.org

Montesinos-lópez OA, Baenziger PS, Eskridge KM, Little RS. 2018. Analysis of genotype-by-environment interaction in winter wheat growth in organic production system 30: 212 223. https://doi.org/10.9755/ejfa.2018.v30.i3.1643

Pilgeram AL, Sands DC, Boss D, Dale N, Wichman D, Lamb P, Lu C, Kirkpatrick M, Thompson B, Johnson DL. 2007. Camelina sativa, A Montana Omega-3 and Fuel Crop. Proc. sixth Natl. Symp. Creat. Mark. Econ. Dev. New Crop. New Uses. 129-131.

Popovic V, Vidic M, Miladinovic J, Ikanovic J, Drazic G, Djukic V, Mihailovic B, Filipovic V, Dozet G, Jovanovic L, Stevanovic P. 2016. Variability of yield and chemical composition in soybean genotypes grown under different agroecological conditions of Serbia. Rom. Agric. Res. 2016.

Putnam DH, Budin JT, Field LA, Breene WM. 1993. Camelina: A promising low-input oilseed. New Crop. John Wiley Sons, New York, NY 314-322.

Robinson RG. 1987. Camelina: a useful research crop and a potential oilseed crop. Minnesota Ag. Expt. Stn. Bull. 5792 12.

Rokka T, Alén K, Valaja J, Ryhänen EL. 2002. The effect of a Camelina sativa enriched diet on the composition and sensory quality of hen eggs. Food Res. Int. 35: 253-256. https://doi.org/10.1016/S0963-9969(01)00193-4

Ryhänen EL, Perttilä S, Tupasela T, Valaja J, Eriksson C, Larkka K. 2007. Effect of Camelina sativa expeller cake on performance and meat quality of broilers. J. Sci. Food Agric. 87: 1489-1494. https://doi.org/10.1002/jsfa.2864

Schuster A, Friedt W. 1998. Glucosinolate content and composition as parameters of quality of Camelina seed. Ind. Crops Prod. 7: 297-302. https://doi.org/10.1016/S09266690(97)00061-7

Silveira DA, Pricinotto LF, Nardino M, Bahry CA, Prete CEC, Cruz L. 2016. Determination of the adaptability and stability of soybean cultivars in different locations and at different sowing times in Paraná state using the AMMI and Eberhart and Russel methods. Semin. Agrar. 37: 3973-3982. https://doi.org/10.5433/1679-0359.2016v37n6p3973

Tyagi AK. 2002. Influence of water soaking of mustard cake on glucosinolate hydrolysis. Anim. Feed Sci. Technol. 99: 215219. https://doi.org/10.1016/S0377-8401(02)00142-6

Vollmann J, Moritz T, Kargl C, Baumgartner S, Wagentristl H. 2007. Agronomic evaluation of camelina genotypes selected for seed quality characteristics. Ind. Crops Prod. 26: 270-277. https://doi.org/10.1016/j.indcrop.2007.03.017

Yan W, Hunt LA. 2001. Interpretation of Genotype 1109-1113.

Yan W, Rajcan I. 2002. Biplot Analysis of Test Sites and Trait Relations of Soybean in Ontario. Crop Sci. 42: 11. https://doi.org/10.2135/cropsci2002.0011 